\title{
STRATEGI KEPALA SEKOLAH DAN IMPLEMENTASINYA DALAM PENINGKATAN KOMPETENSI GURU
}

\author{
KUSEN, RAHMAD HIDAYAT, IRWAN FATHURROCHMAN, HAMENGKUBUWONO \\ INSTITUT AGAMA ISLAM NEGERI (IAIN) CURUP \\ Email : irwan@iaincurup.ac.id
}

\begin{abstract}
:
The main problem facing education today is the quality of human resources are low and not sanggupnya follow the progress of science and technology in the era of globalization, where competition quality menajdi something very urgent met by the school, then you need to do is improve the quality of human resources, both from the aspect of intellectual, spiritual, creativity, morality, and responsibility. This study aims to determines how the principal strategy in improving the competence of teachers in terms of pedagogical, professional, personal and social. This study uses qualitative descriptive approach. It can be concluded that the principal strategy in improving the competence of teachers through empowerment by education supervisors.
\end{abstract}

Keywords: Strategy Principal and Teacher Competence.

\section{PENDAHULUAN}

$\mathrm{M}$ utu sumber daya manusia yang rendah merupakan masalah mendasar yang dapat menghambat pembangunan dalam menghadapi era globalisasi, karena era globalisasi merupakan era persaingan mutu, maka yang perlu dilakukan adalah meningkatkan mutu sumber daya manusia, baik dari aspek intelektual, spiritual, kreativitas, moral, maupun tanggung jawab.

Mulyasa (2004: 4) menjelaskan bahwa mutu sumber daya manusia perlu ditingkatkan, diupayakan secara bertahap dan berkesinambungan melalui pendidikan yang bermutu baik pada jalur pendidikan formal, informal, maupun non formal, mulai dari pendidikan dasar sampai pendidikan tinggi. Dengan kata lain yaitu pentingnya pengembangan sistem pendidikan yang berkualitas perlu lebih ditekankan, karena berbagai indikator menunjukkan bahwa pendidikan yang ada belum mampu menghasilkan sumber daya sesuai dengan perkembangan masyarakat dan kebutuhan pembangunan.

Sehubungan dengan hal tersebut, Sardiman (2005: 125) mengemukakan bahwa guru adalah salah satu komponen penting yang ikut berperan dalam usaha pembentukan sumber daya manusia yang potensial di bidang pendidikan. Oleh karena itu, guru harus berperan secara aktif dan menempatkan kedudukannya sebagai tenaga kompeten, sesuai dengan tuntutan masyarakat yang semakin berkembang. Dalam hal ini guru tidak semata-mata sebagai pengajar, tetapi juga sebagai pendidik nilai-nilai sekaligus sebagai pembimbing yang memberikan pengarahkan dan menuntun siswa dalam belajar. 
Implementasi strategi kepala sekolah dapat berupa hal-hal yang pokok dilakukan (Amin, Suci Larasati, \& Fathurrochman, 2018), sementara itu dalam implementasi dapat kita definisikan sebagai suatu proses penerapan ide, konsep, dan konstruk keilmuan (Fathurrochman, 2017a).

Sardiman (2005: 125) mengemukakan bahwa kualitas guru adalah salah satu komponen penting yang ikut berperan dalam usaha pembentukan sumber daya manusia yang potensial di bidang pendidikan. Oleh karena itu, guru harus berperan secara aktif dan menempatkan kedudukannya sebagai tenaga kompeten, sesuai dengan tuntutan masyarakat yang semakin berkembang. Dalam hal ini guru tidak semata-mata sebagai pengajar, tetapi juga sebagai pendidik nilai-nilai sekaligus sebagai pembimbing yang memberikan pengarahan dan menuntun siswa dalam belajar.

Mutu dari guru tersebut akan mempengaruhi keberhasilan siswa dalam belajar, yang berujung pada peningkatan mutu pendidikan. Untuk itu, guru dituntut lebih kompeten dalam menjalankan tugasnya. Tugas guru menurut Undang-Undang Republik Indonesia Nomor 14 Tahun 2005 pasal 20 Tentang Guru dan Dosen adalah merencanakan pembelajaran, melaksanakan proses pembelajaran yang bermutu, serta menilai dan mengevaluasi hasil pembelajaran. Tugas pokok guru tersebut yang diwujudkan dalam kegiatan belajar mengajar serta tugas-tugas guru dalam kelembagaan marupakan bentuk kompetensi guru. Apabila kompetensi guru meningkat, maka berpengaruh pada peningkatan kualitas keluaran atau outputnya. Oleh karena itu, perlu dukungan dari berbagai pihak sekolah untuk meningkatkan kompetensi guru.

Pidarta dalam Saerozi (2005: 2) menjelaskan bahwa kompetensi guru akan menjadi optimal, bilamana diintegrasikan dengan komponen sekolah, seperti kepala sekolah, kondisi sekolah, guru, karyawan dan anak didik. Ada beberapa faktor yang dapat mempengaruhi kompetensi guru dalam melaksanakan tugasnya yaitu: a) kepemimpinan kepala sekolah, b) iklim sekolah, c) harapan-harapan, dan d) kepercayaan personalia sekolah. Dengan demikian, nampaklah bahwa efektivitas kepemimpinan kepala sekolah dan iklim sekolah akan ikut menentukan baik buruknya kompetensi guru.

Menurut Mulyasa (2004: 25), bahwa keberhasilan pendidikan di sekolah sangat ditentukan oleh kompetensi guru, juga keberhasilan kepala sekolah dalam mengelola tenaga kependidikan yang tersedia di sekolah. Kepala sekolah merupakan salah satu komponen pendidikan yang berpengaruh dalam meningkatkan kompetensi guru. Kepala sekolah bertanggung jawab atas penyelenggaraan kegiatan pendidikan, administrasi sekolah, pembinaan tenaga kependidikan lainnya, dan pendayagunaan serta pemeliharaan sarana dan prasarana $\mathrm{Hal}$ tersebut menjadi lebih penting sejalan dengan semakin kompleksnya tuntutan tugas kepala sekolah, yang menghendaki dukungan kinerja yang semakin efektif dan efisien. 
Berdasarkan hasil observasi diperoleh bahwa kompetensi guru di MTs N 01 Kepahiang baik. Ada beberapa guru yang menjadi guru teladan tingkat Kabupaten Kepahiang. Disiplin guru dalam bekerja juga sudah baik. Hal tersebut ditunjang oleh tata tertib sekolah dimana guru wajib mengisi daftar hadir pada pagi hari sebelum bekerja dan siang hari setelah proses belajar mengajar selesai. Dengan demikian kedisiplinan guru dalam bekerja dapat terpantau. Kepemimpinan Kepala Sekolah MTs N 01 Kepahiang sudah baik, dimana Kepala Sekolah memiliki motivasi yang tinggi untuk memajukan sekolah yang dipimpinnya. Hal tersebut ditunjukkan dengan penambahan fasilitas atau media pembelajaran agar proses pembelajaran berjalan lebih efektif. Kepala Sekolah MTs N 01 Kepahiang melaksanakan kepemimpinan dengan disiplin yang tinggi. Namun bagi sebagian besar guru, disiplin yang diterapkan menjadi beban tersendiri dalam bekerja.

Iklim akademik di sekolah terlihat kurang harmonis, hal tersebut terlihat dari interaksi antara guru dengan kepala sekolah, guru dengan guru, kepala sekolah dengan karyawan belum terlihat harmonis. Demikian juga interaksi dari bawah ke atas, guru hanya menyampaikan laporan hasil belajar siswa maupun hasil kerja dari tugas-tugas lain yang dibebankan kepadanya. Kondisi tersebut menunjukkan bahwa hubungan yang terjadi antara kepala sekolah dengan guru cenderung kaku. Hal tersebut dapat terlihat dari kurangnya keterbukaan dalam berkomunikasi antara kepala sekolah dengan guru, sehingga kompetensi guru dalam mengajar belum maksimal.

\section{STRATEGI KEPALA SEKOLAH}

Burhanudin (2005:4) mengemukakan bahwa strategi merupakan pendekatan secara keseluruhan yang berkaitan dengan pelaksanaan gagasan, perencanaan, dan eksekusi sebuah aktivitas dalam kurun waktu tertentu. Di dalam strategi terdapat koordinasi tim kerja, memiliki tema, mengidentifikasi faktor pendukung yang sesuai dengan prinsip-prinsip pelaksanaan gagasan secara rasional, efisien dalam pendanaan untuk mencapai tujuan secara efektif. kepala sekolah sebagai leader harus mampu memberikan petunjuk dan pengawasan, meningkatkan kemauan tenaga kependidikan, membuka komunikasi dua arah dan mendelegasikan tugas. Kemampuan yang harus diwujudkan kepala sekolah sebagai leader dapat dianalisis dari kepribadian, pengetahuan terhadap tenaga kependidikan, visi dan misi sekolah, kemampuan mengambil keputusan dan kemampuan berkomunikasi. Kepribadian kepala sekolah sebagai leader akan tercermin dalam sifat-sifat jujur, percaya diri, tanggung jawab, berani mengambil resiko dan keputusan, berjiwa besar, emosi yang stabil, teladan (Fathurrochman, 2017b). Pengetahuan kepala sekolah terhadap tenaga kependidikan akan tercermin dalam kemampuan diantara-nya yaitu memahami kondisi tenaga kependidikan (guru dan non guru), memahami kondisi dan karakteristik peserta didik, menyusun program pengembangan tenaga kependidikan, menerima 
masukan dan saran serta kritikan dari berbagai pihak untuk meningkatkan kepemimpinannya.

Implementasinya, kepala sekolah sebagai leader dapat dianalisis dari tiga sifat kepemimpinan yakni demokratis, otoriter, dan laissez faire. Ketiga sifat tersebut sering dimiliki secara bersamaan oleh seorang leader, sehingga dalam melaksanakan kepemimpinannya, sifat-sifat tersebut muncul secara situasional. Oleh karena itu kepala sekolah sebagai leader mungkin bersifat demokratis atau otoriter dan mungkin bersifat laissez faire. Meskipun kepala sekolah ingin selalu bersifat demokratis, namun sering kali situasi dan kondisi menuntut untuk bersikap lain, misalnya harus otoriter. Dalam hal tertentu sifat kepemimpinan otoriter lebih cepat digunakan dalam pengambilan suatu keputusan. Dengan dimilikinya ketiga sifat tersebut oleh seorang kepala sekolah sebagai leader, maka dalam menjalankan roda kepemimpinannya di sekolah, kepala sekolah dapat menggunakan strategi yang tepat, sesuai dengan tingkat kematangan para tenaga kependidikan dan kombinasi yang tepat antara prilaku tugas dan prilaku hubungan. Strategi tersebut dapat dilaksanakan dalam gaya mendikte, menjual, melibatkan dan men-delegasikan. Konflik dapat dikatakan sebagai suatu oposisi atau pertentangan pendapat antara orang-orang, kelompok-kelompok atau organisasiorganisasi, yang disebabkan oleh adanya berbagai macam perkembangan dan perubahan dalam bidang manajemen, serta menimbulnya perbedaan pendapat, keyakinan dan ide (Rozak, Fathurrochman, \& Ristianti, 2018). Dalam pada itu, ketika individu bekerja sama satu sama lain dalam rangka mewujudkan tujuannya, maka wajar seandainya dalam waktu yang cukup lama terjadi perbedaan perbedaan pendapat di antara mereka.

Kepala sekolah perlu menerapkan strategi dalam fungsinya sebagai pemimpin ini berarti bahwa kepemimpinan adalah seni dan ilmu penyusunan, penerapan, dan pengevaluasian keputusan-keputusan lintas fungsional yang dapat memungkinkan suatu lembaga pendidikan mencapai tujuannya. Kepemimpinan adalah proses penetapan tujuan organisasi, pengembangan kebijakan dan perencanaan untuk mencapai sasaran tersebut, serta mengalokasikan sumber daya untuk menerapkan kebijakan dan merencanakan pencapaian tujuan organisasi. Kepemimpinan mengkombinasikan aktivitas-aktivitas dari berbagai bagian fungsional suatu bisnis untuk mencapai tujuan organisasi. Kepemimpinan memberikan arahan menyeluruh untuk lembaga pendidikan dan terkait erat dengan kompetensi guru. Kepemimpinan berbicara tentang gambaran besar apa yang akan dilakukan. Inti dari kepemimpinan adalah mengidentifikasi tujuan organisasi, sumber dayanya, dan bagaimana sumber daya yang ada tersebut dapat digunakan secara paling efektif untuk memenuhi tujuan strategis. Kepemimpinan di saat ini harus memberikan fondasi dasar atau pedoman untuk pengambilan keputusan dalam organisasi (Ristianti, 2017). Ini adalah proses yang berkesinambungan dan terus-menerus. Rencana strategis organisasi merupakan 
dokumen hidup yang selalu dikunjungi dan kembali dikunjungi. Bahkan mungkin sampai perlu dianggap sebagaimana suatu cairan karena sifatnya yang terus harus dimodifikasi. Seiring dengan adanya informasi baru telah tersedia, dia harus digunakan untuk membuat penyesuaian dan revisi.

\section{KOMPETENSI GURU}

Roestiyah (2008: 6) menjelaskan bahwa kompetensi yang dimiliki oleh setiap guru akan menunjukkan kualitas guru dalam mengajar. Louisell D, Robert \& Jorge Descamps. (1992: 27) mengemukakan bahwa kompetensi tersebut akan terwujud dalam bentuk penguasaan pengetahuan dan profesional dalam menjalankan fungsinya sebagai guru. Kompetensi yang diperlukan oleh seseorang tersebut dapat diperoleh baik melalui pendidikan formal maupun pengalaman.. Kompetensi adalah kemampuan atau kecakapan. Pendapat lain dijelaskan (Mulyasa. 2004) mengemukakan bahwa kompetensi sebagai pengetahuan, keterampilan, dan kemampuan yang dikuasai oleh seseorang yang telah menjadi bagian dari dirinya, sehingga ia dapat melakukan perilaku-perilaku kognitif, afektif, dan psiko motorik dengan sebaik-baiknya. Berdasarkan penjelaskan di atas bahwa kompetensi tidak hanya mengandung pengetahuan, keterampilan dan sikap, namun yang penting adalah penerapan dari pengetahuan, keterampilan dan sikap direalisasikan dalam pelaksanaan pekerjaan yang dibebankan kepadanya dengan penuh tanggung jawab sebagai guru yang profesional. Jadi, kompetensi profesional guru dapat diartikan sebagai kemampuan dan kewenangan guru dalam menjalankan profesi keguruannya. Guru yang kompeten dan profesional adalah guru piawai dalam melaksanakan profesinya.Berdasarkan uraian di atas kompetensi guru dapat didefinisikan sebagai penguasaan terhadap pengetahuan, keterampilan, nilai dan sikap yang direfleksikan dalam kebiasaan berpikir dan bertindak dalam menjalankan profesi sebagai guru.

Kompetensi guru dapat diartikan sebagai kebulatan pengetahuan, keterampilan dan sikap yang diwujudkan dalam bentuk perangkat tindakan cerdas dan penuh tanggung jawab yang dimiliki seseorang guru untuk memangku jabatan guru sebagai profesi. Keempat jenis kompetensi guru yang dipersyaratkan beserta subkompetensi dan indikator esensialnya diuraikan sebagai berikut:

\section{Kompetensi Pedagogik}

Kompetensi pedagogik merupakan kemampuan yang berkenaan dengan pemahaman peserta didik dan pengelola pembelajaran yang mendidik dan dialogis. Secara substantif kompetensi ini mencakup kemampuan pemahaman terhadap peserta didik, perancangan dan pelaksanaan pembelajaran, evaluasi hasil belajar, dan pengembangan peserta didik untuk mengaktualisasikan berbagai potensi yang dimilikinya. Secara rinci yang dipaparkan oleh suyatno (2009: 15) masing-masing elemen kompetensi pedagogik tersebut dapat dijabarkan menjadi subkompetensi dan indikator esensial sebagai berikut : (a). memahami peserta didik; 
(b).merancang pembelajaran; (c).melaksanakan pembelajaran; (d).merancang dan melaksanakan evaluasi pembelajaran; (e).mengembangkan peserta didik untuk mengaktualisasikan berbagai potensi yang dimilikinya.

\section{Kompetensi Profesional}

Menurut Undang Undang RI Nomor 14 tahun 2005 bahwa yang dikatakan guru professional adalah “ Guru adalah pendidik professional dan tugas utamanya mendidik, mengajar, membimbing, mengarahkan, melatih, menilai dan mengevaluasi peserta didik pada pendidikan anak usia dini jalur pendidikan formal, pendidikan dasar dan pendidikan menengah". Dalam hal ini profesi banyak memliki konotasi, salah satu diantaranya tenaga kependidikan yang di dalamnya guru. Secara umum profesi adalah sebagai suatu pekerjaan yang memerlukan pendidikan lebih lanjut sebagai perangkat dasar untuk di terapkan dsalam berbagai kegiatan yang bermanfaat. Pekerjaan professional senantiasa menggunakan tekhnik dan prosedur berfikir dalam landasan intelektual yang harus dipelajaqri secara sengaja, terencana dan dipergunakan dalam kemaslahatan umum, dari pendapat di atas ada tiga pokok inti dari pengertian profesi yaitu pengetahuan, keahlian dan persiapan akademik. Pengertian di atas bahwa kompetensi professional adalah kemampuan seseorang menerapkan keahlianya senada dengan pembahasan tesis ini untuk meraih prestasi belajar dengan mengerahkan kemampuan dasar secara maksimal. Menurut Depdikbud $(2009,121)$ kompetensi kemampuan dasar yaitu : (1). penguasaan bahan pelajaran beserta konsep-konsep dasar keilmuannya, (2). pengelolaan program belajar mengajar, (3). pengelolaan kelas, (4). penggunaan media dan sumber pembelajaran, (5). penguasaan landasan pendidikan, (6). pengelolaan fungsi dan program bimbingan konseling, (7). pengenalan dan penyelenggaraan administrasi sekolah, (8). pemahaman prinsip-prinsip dan pemanfaatan hasil penelitian pendidikan untuk kepentingan mutu pengajaran.

\section{Kompetensi Kepribadian}

Kompetensi kepribadian merupakan kemampuan personal yang mencerminkan kepribadian yang mantap, stabil, dewasa, arif, dan berwibawa, menjadi teladan bagi peserta didik, dan berakhlak mulia. Pemahaman tentang kompetensi kepribadian dimaknai sebagai salah satu wujud sosok manusia yang utuh. Sebagai seorang guru sudah selayaknya jadi panutan yang bisa di teladani oleh para peserta didik. Seorang guru dituntut dapat memberikan warna dan motivasi terhadap siswanya untuk berkarya dengan penuh tanggung jawab. Sosok guru teladan diharapkan akan tumbuh juga pada peserta didik menjadi contoh bagi warga sejitar dan masyarakatnya. Secara rinci setiap elemen kepribadian tersebut dapat dijabarkan menjadi sub kompetensi dan indikator esensial sebagai berikut: (a) memiliki kepribadian yang mantap dan stabil; (b) memiliki kepribadian yang 
dewasa; (c) memiliki kepribadian yang arif; (d) memiliki kepribadian yang berwibawa; (e) memiliki akhlak mulia dan dapat menjadi teladan.

\section{Kompetensi Sosial}

Menurut Undang-undang No.14 tahun 2005 tentang Guru dan Dosen kompetensi sosial adalah "kemampuan guru untuk berkomunikasi dan berinteraksi secara efektif dan efisien dengan peserta didik, sesama guru, orangtua/wali peserta didik, dan masyarakat sekitar". Kemudian diperjelas dalam Peraturan Pemerintah RI Nomor 19 Tahun 2005, menjelaskan bahwa kompetensi sosial berkenaan dengan kemampuan pendidik sebagai bagian dari masyarakat untuk berkomunikasi dan bergaul secara efektif dengan peserta didik, sesama pendidik, tenaga kependidikan, orangtua/wali peserta didik, dan masyarakat sekitar. Guru yang efektif adalah guru yang mampu membawa siswanya dengan berhasil mencapai tujuan pengajaran. Mengajar di depan kelas merupakan perwujudan interaksi dalam proses komunikasi. Ada pendapat yang mengatakan bahwa guru sebagai bagian dari masyarakat merupakan salah satu pribadi yang mendapat perhatian khusus di masyarakat. Peranan dan segala tingkah laku yang dilakukan guru senantiasa dipantau oleh masyarakat. Menurut Slavin (2008:180), menjelaskan bahwa guru memiliki kedudukan khusus di masyarakat, oleh karena itu, diperelukan sejumlah kompetensi social yang dimiliki guru dalam berinteraksi dengan lingkungan masyarakat di tempat mereka bertugas.

Kehadiran guru di tengah-tengah masyarakat diharapkan memiliki karakteristik tersendiri sehingga ada yang membedakan bahwa is seorang gureu. Guru mempunyai misi mendidik, mengajar untuk memanusian manusia dengan cara membimbing dan membina anak didik dan masyarakat kea rah norma yang ada baik adat, social dan agama yang berlaku di masyarakat. Dengan adanya kerjasama antara guru dengan baik maka permasalahan-permasalahan di sekolah akan dapat diselesaikan dengan baik.

Berdasarkan uraian di atas memberi gambaran bahwa salah strategi kongkrit untuk mendorong produktifitas menurut Syaefudin U.S.( 2009: 36) adalah dengan membina dan mengembangkan etos kompetensi guru yang baik. Disamping peningkatan pendidikan dan ke terampilan guru agar mampu mengemban tugas dan pekerjaan dengan sebaik-baiknya. Etos kinerja bermanfaat dan berguna jika dilaksanakan di tempat dimana guru itu bekerja,karena etos kinerja memberikan kontribusi,karena kinerja memberikan kontribusi sebagai berikut : (1) memberikan kepuasaan, sebab telah melakukan hal terbaik dalam melaksanakan pekerjaan sebagai guru yang bertanggung jawab; (2) pelaksanaan etos kinerja secara kompak menjadikan iklim kerja yang sehat, suasana kerja yang tenang, tentram dan menyenangkan; (3) mendorong untuk bekerja secara tertib, tenang, teratur dan nyaman. Etos kinerja yang dilaksanakan secara merata akan menghilangkan kecemburuan sosial, tidak saling menyalahkan, dan saling mencurigai karena 
masing-masing sudah mengetahui tugasnya; (4) kepala sekolah mempunyai peranan yang penting dalam organisasi sekolah, ini berarti bahwa apa yang dikerjakannya akan sangat berpengaruh terhadap jalannya proses pendidikan di sekolah, sehingga secara ideal kinerja kepala sekolah harus dapat menciptakan situasi organisasi pendidikan sekolah yang efektif. Kualitas kinerja kepala sekolah akan sangat ditentukan oleh bagaimana seorang kepala melaksanakan tugas dan fungsinya dalam mengelola pendidikan di sekolah sesuai dengan kemampuan dan motivasi kerjanya.

Kepala sekolah adalah penangggung jawab seluruh kegiatan proses Pendidikan di sekolah, sehingga peranannya sangat dominan bagi terselenggaranya seluruh kegiatan di Sekolah, segala permasalahan yang dihadapi oleh seluruh komponen yang terlibat di sekolah harus mampu dipecahkan dan diatasi oleh kepala sekolah, sehingga situasi menjadi kondusif bagi pengembangan seluruh potensi sumber daya yang terkait. Dengan sumber daya yang bervariasi, kepala sekolah dituntut untuk menyatukan menjadi suatu kekuatan yang terintegrasi dan terarah pada proses pencapaian bersama, dia harus mampu mengembangkan visi dan misi tidak hanya sekedar menyatakannya. Upaya menjadikan seluruh komponen di sekolah menjadi suatu pedoman memerlukan pemahaman karakteristik dan potensi setiap individu serta pemahaman dan penguasaan tentang bagaimana membuat semua itu bersinergi sehingga dapat terwujud satu tujuan (pelaksanaan misi) yang sesuai dengan yang diharapkan. Semua itu menunjukan bahwa peran kepala sekolah sangat penting dan sangat berat dalam mengelola sekolah guna mencapai tujuan pendidikan sekolah.

Dengan melihat empat dimensi tersebut di atas nampak sekali bahwa tugas yang diemban oleh kepala sekolah cukup berat, oleh karena itu dalam melaksanakan tugasnya Kepala sekolah harus memiliki berbagai persyaratan tertentu agar la dapat menjalankan tugasnya dengan baik, menurut (Burhanudin. 2005), peran dan fungsi kepala sekolah adalah sebagai administrator dan Supervisor, lebih jauh Wahjosumidjo. (1999:47) mengelom-pokkan peran kepala sekolah ke dalam : (1) kepala sekolah sebagai pejabat formal; (2) kepala sekolah sebagai manajer; (3) kepala sekolah sebagai seorang pemimpin; (4) kepala sekolah sebagai pendidik; (5) kepala sekolah sebagai staff.

\section{METODE PENELITIAN}

Penelitian ini menggunakan metode kualitatif dengan pendekatan deskriptif. Dalam penelitian ini, peneliti menguraikan secara komprehensif mengenai strategi yang dilakukan oleh kepala sekolah di MTs N 01 Kepahiang dalam meningkatkan kompetensi guru, dengan menjelaskan keadaan yang terjadi, sehingga dalam penelitian yang mengangkat masalah strategi yang dilakukan oleh Kepala Sekolah.

Subjek penelitian adalah kepala sekolah dan guru pada MTs N 01 Kepahiang, Provinsi Bengkulu, dengan teknik pengumpulan data melalui wawancara, 
observasi, dan dokumentasi. Teknik analisis data menggunakan metode yang dikembangkan oleh (Miles \& Huberman, 1984) dengan tiga langkah, yaitu reduksi data, penyajian data, dan kesimpulan. Keabsahan data dilakukan dengan menggunakan teknik triangulasi.

\section{HASIL PENELITIAN DAN PEMBAHASAN}

\section{Strategi Kepala Sekolah dalam Meningkatkan Kompetensi Pedagogi}

Kompetensi pedagogik yang dimiliki oleh guru harus dapat dimaknai dengan bijak. Oleh sebab itu harus diketahui guru untuk mengetahui dalam kompetensi pedagogik.

\section{a. Memahami Peserta Didik}

Sebagai seorang guru sangat penting memahami peserta didik. Sebab dengan memahami perkembangan peserta didik, guru akan dapat memberikan pembelajaran yang sesuai dengan apa yang diinginkan oleh peserta didik. Artinya siswa nanti akan menjadi apa. Berdasarkan informasi yang disampaikan oleh kepala sekolah sebagai informen, mengatakan bahwa:

Guru yang mengajar di MTs N 01 Kepahiang belum optimal memahami perkembangan peserta didik i pada guru yang mengajar al-qur'an hadits, tidak semua siswa lancar dan memahami membaca al-qur'an atau hafalan dengan baik, sehingga ada siswa yang merasa cemas dalam belajar hal tersebut menjadi penyebab peserta didik belum terlihat perkembangan dalam kemajuan yang mantap dalam belajar. Perkembangan pada diri peserta didik bukan tanpa proses, melainkan sebagai hasil interaksi dari kemajuan dalam mengikuti pembelajaran. (wawancara dengan Romzi, S.Pd., M.M, Kepala Sekolah MTs N 01 Kepahiang tanggal 10 April 2017).

Sehubungan dengan hal tersebut Bapak Drs. Alimuddin menjelaskan:

Guru yang mengajar di MTs N 01 Kepahiang belum memperhatikan kondisi belajar siswa, sehingga guru belum mengetahui sejauhmana perkembangan peserta didik, sehingga apa yang disampaikan guru kepada siswanya belum dapat dipahami dengan baik. (wawancara dengan Bapak Drs. Alimuddin, Guru Bahasa Arab MTs 01 Kepahiang, tanggal 10 April 2017).

Sebagai guru hendaknya mampu memamahami peserta didik dengan memanfaatkan prinsip-prinsip perkembangan kognitif. Artinya bahwa pertumbuhan dan perkembangan kognitif peserta didik berhubungan dengan perubahan struktur dan fungsi karakteristik pada diri peserta didik itu sendiri. Guru mempunyai tugas untuk memahami bagaimana peserta didik mengalami perkembangan inteletualnya dan menetapkan kegiatan kognitif yang harus ditampilkan pada 
kegiatan pembelajaran. Pemahaman ini akan membantu guru dalam melaksanakan tugasnya sebagai pendidik.

Sehubungan dengan hal tersebut Kepala Sekolah menjelaskan bahwa:

Guru yang mengajar di MTs N 01 Kepahiang belum optimal memanfaat-kan prinsip-prinsip kognitif peserta didik. Guru hanya sebatas menyam-paikan apa yang ada dalam buku tanpa memberikan makna yang jelas kepada siswa, sehingga siswa tidak biasa untuk mengembangkan kemampuan yang ada dalam diri mereka. (wawancara dengan Romzi, S.Pd., M.M, Kepala Sekolah MTs N 01 Kepahiang tanggal 10 April 2017).

Berdasarkan penjelasan tersebut di atas dapat dipahami bahwa guru belum memahami prinsip perkembangan kognitif siswa, sehingga guru dalam mengajar hanya menyampaikan apa yang ada dalam buku tanpa dapat mengembangkan apa yang dibutuhkan oleh siswa, untuk itu, guru harus mengetahui prinsip kognitif siswa sehingga guru dapat menyampaikan materi pembelajaran sesuai dengan kebutuhan siswa.

\section{b. Merancang Pembelajaran}

Merancang pembelajaran merupakan hal yang sangat penting, hal yang demikian termasuk upaya untuk memahami landasan pendidikan untuk kepentingan pembelajaran. Pemahaman yang demikian merupakan kemampuan yang harus dimiliki oleh guru. Dalam perencanaan pembelajaran mencakup tiga hal, yaitu: identifikasi kebutuhan, perumusan kompetensi dasar, dan penyusunan program pembelajaran.

Penyusunan program pembelajaran akan bermuara pada rencana pelaksanaan pembelajaran (RPP) sebagai produk program pembelajaran jangka pendek, yang mencakup komponen program kegiatan belajar dan proses pelaksanaan program.

Hasil penelitian menunjukkan bahwa guru yang mengajar di MTs N 01 Kepahiang dalam hal persiapan perencanaan pembelajaran sering terlambat untuk melaksanakan pembelajaran di awal semester. Hal tersebut sebagaimana dijelaskan yaitu:

Guru yang mengajar sering terlambat dalam menyiapkan bahan ajar termasuk silsbus, dan RPP, sehingga guru sering membuat persiapan bahan ajar itu tidak sesuai dengan kondidi kebutuhan siswa, dengan demikian, maka kondisi yang demikian jelas, guru tidak memahami perkembangan peserta didi, termasuk berkenaan dengan apa yang dibutuhkan oleh peserta didik. Sebagai guru perlu persiapan mengajar yang terencana dengan baik, sehingga hasilnya nanti akan baik pula. Dari awal sudah direncanakan 
dengan baik, maka proses pembelajarannya akan sesuai dengan tujuan yang telah direncanakan semula. (Wawancara dengan Bapak Suharto, S.Ag Kepala Tata Usaha MTs. 01 Kepahiang, 10 April 2017).

\section{c. Melaksanakan Pembelajaran yang Kondusif}

Pembelajaran merupakan proses interaksi antara peserta didik dengan lingkungannya, sehingga terjadi perubahan perilaku ke arah yang lebih baik. Dalam pembelajaran tugas guru yang paling utama adalah mengkondisikan lingkungan agar menunjang terjadinya perubahan perilaku dan pembentukan kompetensi peserta didik. Pelaksanaan pembelajaran mencakup, pretest, proses dan posttest.

Sehubungan dengan hal tersebut, berdasarkan informasi dapat dijelaskan oleh responden bahwa:

Proses belajar mengajar belum berjalan secara optimal dan terlihat kurang interaktif. Karena guru mengajar masih menggunakan metode konvesional, anti dialog, dan bersifat ceramah semata. Kondisi yang demikian membuat peserta didik menjadi kurang respon dalam mengikuti pembelajaran tersebut. Guru hendaknya dapat menerapkan metode pembelajar-an yang bersifat membangun semangat belajar siswa, sehingga dalam pembelajara akan tercipta proses interaksi antara siswa dengan guru, siswa dengan siswa. Untuk itu guru hendaknya juga mampu memancing suasana yang sehat, melalui pre tes, dengan demikian siswa akan termotivasi dalam belajar. (wawancara dengan Bapak Ali Hanafi, S.Ag, Wakil Kepala Sekolah, tanggal 10 April 2017).

\section{d. Merancang dan Melaksanakan Evaluasi Pembelajaran}

Merancang pembelajaran merupakan kegiatan belajar mengajar yang dirancang oleh guru sangat penting artinya alam proses belajar mengajar. Hal yang demikian merupakan salah satu peran yang utama dalam proses pembelajaran.

Kemampuan dalam merancang perlu dimiliki oleh guru agar dapat merencanakan dan mengevaluasi peserta didik. Sebab evaluasi hasil belajar dilakukan untuk mengetahui perubahan perilaku dan pembentukan kompetensi peserta didik yang dapat dilakukan melalui penilaian kelas, tes kemampuan dasar, penilaian akhir satuan pendidikan.

Guru yang mengajar di MTs N 01 Kepahiang sudah melaksanakan evaluasi, namun pelaksanaan evaluasi tersebut belum sesuai dengan hasil yang diterima oleh peserta didik. Penilaian tersebut belum objektif. Sebagai guru, hendaknya di dalam memberi penilaian kepada peserta didiknya, hendaknya objektif dan sesuai dengan apa adanya, sehingga kemampuan yang dimiliki oleh peserta didik benar-benar dapat dimiliki. (wawancara dengan Romzi, S.Pd.,M.M, Kepala Sekolah tanggal 12 April 2017). 


\section{e. Mengembangkan Kompetensi Peserta Didik}

Pengembangan peserta didik dapat dilakukan oleh guru melalui berbagai cara, yaitu melalui kegiatan ekstrakurikuler, pengayaan, dan bimbingan konseling.

Guru yang mengajar di MTs N 01 Kepahiang sudah memberikan informasi berbagai kegiatan ekstra kurikuler seperti paduan suara, pramuka, olah raga, kesenian, dan masih banyak lainnya. Namun kegiatan tersebut belum optimal dilaksanakan. Sebab perlu dana yang besar. (wawancara dengan Romzi, S.Pd.,M.M, kepala sekolah, tanggal 12 April 2017).

Demikian pula dengan siswanya, banyak berbagai kegiatan yang disumbangkan ke madrasah, sebagai konsekuensinya dalam mengembangkan potensi dalam diri peserta didik. Juara 1 lomba MTQ TK SLTP/MTs tahun 2001. juara 2 lomba MTQ Tk Provinsi pada tahun 2002. Juara 3 lomba pidato Bahasa Inggris tahun 2002. Juara 1 lomba Cepat Tepat Tk MTs tahun 2003. Juara 1 siswa berprestasi pada tahun 2003, dan masih banyak prestasi yang diukir dari peserta didik MTs N 01 Kepahiang tersebut.

Kepala sekolah sebagai pemimpin tertinggi di madrasah harus mampu memberikan petunjuk dan pengawasan, meningkatkan kemauan tenaga kependidikan, membuka komunikasi dua arah dan mendelegasikan tugas. Kemampuan yang harus diwujudkan kepala sekolah sebagai leader dapat dianalisis dari kepribadian, pengetahuan terhadap tenaga kependidikan, visi dan misi sekolah, kemampuan mengambil keputusan dan kemampuan berkomunikasi. Kepribadian kepala sekolah sebagai leader akan tercermin dalam sifat-sifat jujur, percaya diri, tanggung jawab, berani mengambil resiko dan keputusan, berjiwa besar, emosi yang stabil, teladan. Pengetahuan kepala sekolah terhadap tenaga kependidikan akan tercermin dalam kemampuan diantara-nya yaitu memahami kondisi tenaga kependidikan (guru dan non guru), memahami kondisi dan karakteristik peserta didik, menyusun program pengembangan tenaga kependidikan, menerima masukan dan saran serta kritikan dari berbagai pihak untuk meningkatkan kepemimpinannya.

Dalam implementasinya, kepala sekolah sebagai leader dapat dianalisis dari tiga sifat kepemimpinan yakni demokratis, otoriter, laissez faire. Ketiga sifat tersebut sering dimiliki secara bersamaan oleh seorang leader, sehingga dalam melaksanakan kepemimpinannya, sifat-sifat tersebut muncul secara situasional. Oleh karena itu kepala sekolah sebagai leader mungkin bersifat demokratis atau otoriter dan mungkin bersifat laissez faire. Meskipun kepala sekolah ingin selalu bersifat demokratis, namun sering kali situasi dan kondisi menuntut untuk bersikap lain, misalnya harus otoriter. Dalam hal tertentu sifat kepemimpinan otoriter lebih cepat digunakan dalam pengambilan suatu keputusan. 
Kepala sekolah sebagai pemimpin harus dapat menciptakan kondisi belajar di sekolah yang dipimpinnya tidak menimbulkan konflik. Sebab konflik dapat dikatakan sebagai suatu oposisi atau pertentangan pendapat antara orang-orang, kelompok-kelompok atau organisasi-organisasi, yang disebabkan oleh adanya berbagai macam perkembangan dan perubahan dalam bidang manajemen, serta menimbulnya perbedaan pendapat, keyakinan dan ide. Dalam pada itu, ketika individu bekerja sama satu sama lain dalam rangka mewujudkan tujuannya, maka wajar seandainya dalam waktu yang cukup lama terjadi perbedaan perbedaan pendapat diantara mereka. Untuk meminimalisir hal seperti tersebut di atas seorang kepala sekolah perlu menerapkan kepemimpinan.

\section{Strategi Kepala Sekolah dalam Meningkatkan Kompetensi Profesional}

Kompetensi professional merupakan kemampuan dalam penguasaan materi pembelajaran yang diajar. Menguasai substansi keilmuan yang terkait dengan bidang studi. Memahami materi ajar yang ada dalam kurikulum sekolah; memahami struktur, konsep dan metode keilmuan yang menaungi atau koheren dengan materi ajar; memahami hubungan konsep antar mata pelajaran terkait; dan menerapkan konsep-konsep keilmuan dalam kehidupan sehari-hari. Menguasai langkah-langkah penelitian dan kajian kritis untuk menambah awasan dan memperdalam pengetahuan/materi bidang studi.

Sebagian besar guru yang mengajar di MTs N 01 Kepahiang belum sesuai dengan latar belakang pendidikan yang ditempuh terhadap mata pelajaran yang diampunya, sehingga dalam proses pembelajaran guru terlihat belum menguasai materi pembelajaran dengan baik. Permasa-lahannya adalah masih kekurangan guru yang berdasarkan mata pelajaran tersebut kurang, seperti yang mengajar bahasa Arab dari S1 Pendidikan Agama Islam. (wawancara dengan Romzi, S.Pd.,M.M, kepala sekolah, tanggal 13 April 2017).

Oleh sebab itu, sebagai guru juga menguasai metode pembelajaran yang baik, sehingga dalam proses pembelajaran siswa dapat mengikuti dengan semangat.

Guru yang mengajar masih banyak menggunakan metode ceramah saja, sehingga siswa kurang termotivasi dengan pembelajaran yang terjadi. Misalnya figh. Mata pelajaran ini banyak menghendaki metode contoh atau memperagakan, seperti masalah shalat. (wawancara dengan bapak Romzi, S.Pd.,M.M kepala sekolah, tanggal 12 April 2017).

Upaya untuk mengembangkan potensi peserta didik agar menjadi manuysia yang beriman dan bertaqwa kepada Tuhan Yang Maha Esa, berakhlak mulia, sehat, berilmu, cakap, kreatif dan mandiri, sebagaimana yang termaktub dalam undang- 
undang Sistem pendidikan Nasional. Dengan melakukan pengamatan, baik secara langsung atau secara tidak langsung terhadap penguasaan keilmuan guru yang mengajar di MTs N 01 Kepahiang, melalui supervisi ke kelas sesuai dengan kondisi yang terjadi.

Kompetensi profesional merupakan yang berkenaan dengan penguasaan materi pembelajaran bidang studi secara luas dan mendalam yang mencakup penguasaan substansi isi materi kurikulum mata pelajaran di sekolah dan substansi keilmuan yang manungi materi kurikulum tersebut, serta menambah wawasan keilmuan sebagai guru.

Dalam Undang Undang RI Nomor 14 tahun 2005 bahwa yang dikatakan guru professional adalah Guru adalah pendidik professional dan tugas utamanya mendidik, mengajar, membimbing, mengarahkan, melatih, menilai dan mengevaluasi peserta didik pada pendidikan anak usia dini jalur pendidikan formal, pendidikan dasar dan pendidikan menengah. Kata professional diartikan sebagai“ pekerjaan atau kegiatan yang dilakukan oleh seseorang yang menjadi sumber penghasilan kehidupan yang memerlukan keahlian, kemahiran atau kecakapan yang memenuhi standar mutu atau norma tertentu serta memerlukan pendidikan profesi.

Sebagai seorang guru, penguasaan dalam bidang yang asuhnya sangat penting. Namun guru-guru yang mengajar di MTs N 01 Kepahiang masih ada yang belum sesuai dengan bidang mata pelajaran yang di asuh terhadap latar belakang yang ditempuhnya. Misal guru dari S1 PAI mengajar Bahasa Arab. Untuk itu, saya sebagai kepala sekolah akan menyampaikan kekurangan tersebut ke Kanwil Depag Provinsi Bengkulu agar kekurangan guru perlu untuk ditambah sesuai dengan permohonan tersebut.

Di samping itu, guru yang mengajar di MTs N 01 Kepahiang perlu belajar teknologi agar proses pembelajaran dapat memberikan hasil yang lebih baik. Kemudian para guru hendaknya dalam mengajar harus disesuai materi dengan metode, sehingga kondisi belajar siswa termotivasi.

\section{Strategi Kepala Sekolah dalam Meningkatkan Kompetensi Kepribadian}

Kompetensi kepribadian merupakan kemampuan personal yang mencerminkan kepribadian yang mantap, stabil, dewasa, arif, dan berwibawa, menjadi teladan bagi peserta didik, dan berakhlak mulia. Pemahaman tentang kompetensi kepribadian dimaknai sebagai salah satu wujud sosok manusia yang utuh. Sebagai seorang guru sudah selayaknya jadi panutan yang bisa di teladani oleh para peserta didik. Seorang guru dituntut dapat memberikan warna dan motivasi terhadap siswanya untuk berkarya dengan penuh tanggung jawab. Sosok guru teladan diharapkan akan tumbuh juga pada peserta didik menjadi contoh bagi warga sekitar dan masyarakatnya. 
Memiliki kepribadian yang mantap dan stabil. Bertindak sesuai dengan norma hukum, bertindak sesuai dengan norma sosial, bangga sebagai pendidik; dan memeliki konsistensi dalam bertindak sesuai dengan norma. Memiliki kepribadian yang dewasa. Menampilkan kemandirian dalam bertindak sebagai pendidik dan memiliki etos kerja sebagai pendidik. Memiliki kepribadian yang arif. Menampilkan tindakan yang didasarkan pada kemanfaatan peserta didik, sekolah, dan masyarakat dan menunjukkan keterbukaan dalam berpikir dan bertindak.

Memiliki kepribadian yang berwibawa. Memiliki perilaku yang berpengaruh positif terhadap peserta didik dan memiliki perilaku yang disegani. Memiliki akhlak mulia dan dapat menjadi teladan. Bertindak sesuai dengan norma religius (imtaq, jujur, ikhlas, suka menolong), dan memiliki perilaku yang diteladani peserta didik.

Kompetensi kepribadian merupakan kemampuan personal yang mencerminkan kepribadian yang mantap, stabil, dewasa, arif, dan berwibawa, menjadi teladan bagi peserta didik, dan berakhlak mulia. Pemahaman tentang kompetensi kepribadian dimaknai sebagai salah satu wujud sosok manusia yang utuh. Sebagai seorang guru sudah selayaknya jadi panutan yang bisa di teladani oleh para peserta didik. Seorang guru dituntut dapat memberikan warna dan motivasi terhadap siswanya untuk berkarya dengan penuh tanggung jawab. Sosok guru teladan diharapkan akan tumbuh juga pada peserta didik menjadi contoh bagi warga sejitar dan masyarakatnya.

Sebagai guru juga hendaknya memperlihatkan pribadi yang dewasa, misalnya marah, jangan langsung mukul, memaki siswa dan sebagainya. Tunjukkan bahwa sebagai guru adalah contoh teladan yang baik di hadapan siswanya.

\section{Strategi Kepala Sekolah dalam Meningkatkan Kompetensi Sosial}

Kompetensi sosial berkenaan dengan kemampuan pendidik sebagai bagian dari masyarakat untuk berkomunikasi dan bergaul secara efektif dengan peserta didik, sesama pendidik, tenaga kependidikan, orangtua/wali peserta didik, dan masyarakat sekitar (PP RI Nomor 19 tahun 2005). Guru yang efektif adalah guru yang mampu membawa siswanya dengan berhasil mencapai tujuan pengajaran. Mengajar di depan kelas merupakan perwujudan interaksi dalam proses komunikasi.

Menurut Undang-undang No.14 tahun 2005 tentang Guru dan Dosen kompetensi sosial adalah "kemampuan guru untuk berkomunikasi dan berinteraksi secara efektif dan efisien dengan peserta didik, sesama guru, orangtua/wali peserta didik, dan masyarakat sekitar".

Kehadiran guru di tengah-tengah masyarakat diharapkan memiliki karakteristik tersendiri sehingga ada yang membedakan bahwa is seorang gureu. Guru mempunyai misi mendidik, mengajar untuk memanusian manusia dengan cara membimbing dan membina anak didik dan masyarakat kea rah norma yang ada baik adat, sosial dan agama yang berlaku di masyarakat. Dengan adanya 
kerjasama antara guru dengan baik maka permasalahan-permasalahan di sekolah akan dapat diselesaikan dengan baik.

Kompetensi ini memiliki oleh guru MTs N 01 Kepahiang dalam berkomunikasi dan bergaul secara efektif dengan peserta didik. Berkomunikasi secara efektif dengan peserta didik. Mampu berkomunikasi dan bergaul secara efektif dengan sesama pendidik dan tenaga kependidikan. Mampu berkomunikasi dan bergaul secara efektif dengan orang tua/wali peserta didik dan masyarakat sekitar.

Guru yang mengajar di MTs N 01 Kepahiang belum menjembatani permasalahan siswa di sekolah dengan keberadaan siswa di rumah, hal tersebut dikarenakan jauhnya jarak tempat tinggal siswa dengan sekolah. Sehingga komunikasi tersebut belum terbangun dari guru. Sebagai guru, saya memang sering memperhatikan siswa yang ikut belajar dengan saya ketika saya suruh menghafal ayat, mudah lupa, ketika ditanya kelihatan bingung, saya berpikir ada apa dengan diri siswa tersebut. Ini perlu mendapat perhatian yang serius agar siswa tidak merasa minder atau takut mengikuti proses pembelajaran. (wawancara dengan bapak Romzi, S.Pd.,M.M, kepala sekolah, tanggal 12 April 2017).

Guru hendaknnya mampu berkomunikasi kepada siswa dengan baik, mampu menjembatani permasalahan siswa di sekolah dan di rumah, dinama siswa tinggal. Namun permasalahan yang dialami adalah belum terbangun komunikasi sekolah dengan di rumah. Untuk itu sekolah perlu menciptakan kemampuan guru dalam mengatasi permasalahan siswa di sekolah dan di rumah, sehingga proses pembelajaran dapat berjalan dengan baik dan siswa dapat meningkatkan kualitas dalam belajarnya.

Kehadiran guru di tengah-tengah masyarakat diharapkan memiliki karakteristik tersendiri sehingga ada yang membedakan bahwa dia adalah seorang guru. Guru mempunyai misi mendidik, mengajar untuk memanusiakan manusia dengan cara membimbing dan membina anak didik dan masyarakat ke arah norma yang ada baik adat, sosial, dan agama yang berlaku di masyarakat. Dengan adanya kerjasama antara guru dengan baik, maka permasalahan-permasalahan di sekolah akan dapat diselesaikan dengan baik.

Kepala sekolah mempunyai peranan yang penting dalam organisasi sekolah, ini berarti bahwa apa yang dikerjakannya akan sangat berpengaruh terhadap jalannya proses pendidikan di sekolah, sehingga secara ideal kinerja kepala sekolah harus dapat menciptakan situasi organisasi pendidikan sekolah yang efektif. Kualitas kinerja kepala sekolah akan sangat ditentukan oleh bagaimana seorang kepala melaksanakan tugas dan fungsinya dalam mengelola pendidikan di sekolah sesuai dengan kemampuan dan motivasi kerjanya. 
Kepala sekolah adalah penangggung jawab seluruh kegiatan proses Pendidikan di sekolah, sehingga peranannya sangat dominan bagi terselenggaranya seluruh kegiatan di sekolah, segala permasalahan yang dihadapi oleh seluruh komponen yang terlibat di sekolah harus mampu dipecahkan dan diatasi oleh kepala sekolah, sehingga situasi menjadi kondusif bagi pengembangan seluruh potensi sumber daya yang terkait. Dengan sumber daya yang bervariasi, kepala sekolah dituntut untuk menyatukan menjadi suatu kekuatan yang terintegrasi dan terarah pada proses pencapaian bersama, dia harus mampu mengembangkan visi dan misi tidak hanya sekedar menyatakannya.

Upaya menjadikan seluruh komponen di sekolah menjadi suatu pedoman memerlukan pemahaman karakteristik dan potensi setiap individu serta pemahaman dan penguasaan tentang bagaimana membuat semua itu bersinergi sehingga dapat terwujud satu tujuan (pelaksanaan misi) yang sesuai dengan yang diharapkan. Semua itu menunjukkan bahwa peran kepala sekolah sangat penting dan sangat berat dalam mengelola sekolah guna mencapai tujuan pendidikan sekolah.

Dengan melihat empat dimensi tersebut di atas nampak sekali bahwa tugas yang diemban oleh kepala sekolah cukup berat, oleh karena itu dalam melaksanakan tugasnya Kepala sekolah harus memiliki berbagai persyaratan tertentu agar ia dapat menjalankan tugasnya dengan baik, menurut Yusak Burhanudin (2005:14), peran dan fungsi kepala sekolah adalah sebagai administrator dan supervisor, lebih jauh Wahjosumidjo. (1999:47) mengelompokkan peran kepala sekolah ke dalam: (1) kepala sekolah sebagai pejabat formal; (2) kepala sekolah sebagai manajer; (3) kepala sekolah sebagai seorang pemimpin; (4) kepala sekolah sebagai pendidik; (5) kepala sekolah sebagai staf.

\section{PENUTUP/SIMPULAN}

Strategi kepala sekolah dalam meningkatkan kompetensi guru pada kompetensi pedagogik di MTs N 01 Kepahiang yaitu menciptakan suasana kantor yang nyaman, sehingga guru dapat menjalankan tugasnya dengan baik, kondisi yang demikian sangat diperlukan dalam meningkatkan kompetensi pada guru. Demikian pula dengan kompetensi profesionalisme di MTs N 01 Kepahiang bahwa strategi kepala sekolah dapat memberikan peningkatan yang baik kepada guru dapat menjalankan tugasnya berdasarkan latar belakang pendidikan guru sehingga guru menguasai apa yang disampaikan kepada siswanya, menjadikan siswanya lebih memahami apa yang disampaikan guru.

Strategi kepala sekolah dalam meningkatkan kompetensi guru pada kompetensi kepribadian di MTs N 01 Kepahiang dimana kepala sekolah telah memberikan contoh kepribadian yang baik kepada guru, sehingga akhlak guru dalam mengajar memberikan dampak yang positif. Sebab kepribadian seorang 
kepala sekolah akan memberikan pengaruh yang besar dalam menjalankan kepemimpinannya, santun dalam berbicara, ramah dalam bertingkah laku, memjadikan guru nyaman dalam mengajar, Strategi kepala sekolah dalam meningkatkan kompetensi guru pada kompetensi sosial di MTs N 01 Kepahiang hal tersebut menujukkan bahwa kepala sekolah memberikan hubungan komunikasi yang baik dalam sosial di MTs N 01 Kepahiang, sehingga tidak ada rasa takut atau cemas dalam berkomunikasi. Dengan demikian guru menjadi lebih baik dalam bersosialisasi di MTs N 01 Kepahiang.

\section{DAFTAR PUSTAKA}

Amin, M., Suci Larasati, S., \& Fathurrochman, I. (2018). IMPLEMENTASI MANAJEMEN KESISWAAN DALAM MENINGKATKAN PRESTASI NON AKADEMIK DI SMP KREATIF 'AISYIYAH REJANG LEBONG. Journal LITERASIOLOGI, 1(1), 103-121. https://doi.org/10.1017/CB09781107415324.004.

Bungin, Burhan, (2007). Penelitian Kualitatif. Jakarta Kencana Prenada Media Group.

Burhanudin, Yusak. (2005), Analisis Administrasi Manajemen dan Kepemimpinan Pendidikan, Jakarta, Bumi Aksara.

Danim, Sudarwan. (2002). Inovasi Pendidikan Dalam Rangka Peningkatan Profesionalisme Tenaga Kependidikan. Bandung: Pustaka Setia.

Danim, Sudarwan. (2002). Menjadi Peneliti Kualitatif ,Bandung, Pustaka Setia.

Departemen Pendidikan Nasional, (2009). Pedoman Pelaksanaan Tugas Guru dan Pengawas. Jakarta: Direktorat Jendral Peningkatan Mutu Pendidikan dan Tenaga Kependidikan.

Fajri Z Em, Senja R.A (Edisi Revisi) Kamus Lengkap Bahasa Indonesia: Aneka Ilmu Difa Publisher.

Fathurrochman, I. (2017a). Implementasi Manajemen Kurikulum Dalam Upaya Meningkatkan Mutu Santri Pondok Pesantren Hidayatullah / Panti Asuhan Anak Soleh Curup Irwan Fathurrochman A. Pendahuluan Pesantren menurut pengertian dasarnya adalah tempat belajar para santri . Sebagai lemba. Tadbir, 1(01).

Fathurrochman, I. (2017b). Pengembangan kompetensi pegawai aparatur sipil negara ( asn ) sekolah tinggi agama islam negeri ( stain ) curup. Manajer Pendidikan, 11(21), 120-129.

Louisell D, Robert \& Jorge Descamps. (1992). Developing a Teaching Style. NewYork. HarperCollins Publishers. 
Marhijanto, Bambang. (2009). Kamus Lengkap Bahasa Indonesia. Surabaya: Terang

Miles dan Huberman. (2007). Analisis Data Kualitatif. Jakarta : Universitas Indonesia-Press.

Moleong, Lexy.J. (2002). Metodologi Penelitian Kualitatif. Bandung: PT. Remaja Rosdakarya.

Mulyasa, (2002). Manajemen Berbasis Sekolah Konsep, Strategi dan Implementasi. (Bandung PT Raja Grafindo Persada

Mulyasa. (2004). Kurikulum Berbasis Kompetensi. Konsep dan Implementasi. Bandung, PT. Remaja Rosdakarya.

Peraturan Pemerintah Nomor 19 Tahun 2005 Tentang Standar Nasional Pendidikan. Jakarta: JP.Aksara.

Rebecca M.Saunders. (2006). Strategi Penilaian Kinerja Karyawan.Alih Bahas At'Line.Yogyakarta Penerbit TuguPublisher

Republik Indonesia, Kepmen PAN Nomor 118 tahun 1996 tentang Pengawas Sekolah.

Republik Indonesia, PP Nomor 19/2005 tentang Standar Nasional Pendidikan.

Richard I Arends. (1997). Classroom Instruction and Management. McGraw-Hill

Ristianti, D. H. (2017). Analisis Hubungan Interpersonal Mahasiswa terhadap Dosen dalam Proses Bimbingan Skripsi. ISLAMIC COUNSELING: Jurnal Bimbingan Konseling Islam, $1(1), \quad 25$. https://doi.org/10.29240/jbk.v1i1.229

Roestiyah.(2008). Strategi Belajar Mengajar. Bandung: Epsilon.

Rozak, A., Fathurrochman, I., \& Ristianti, D. H. (2018). ANALISIS PELAKSANAAN BIMBINGAN BELAJAR DALAM MENGATASI KESULITAN BELAJAR SISWA. Journal of Education and Instruction (JOEAI), 1(1), 10-20. https://doi.org/10.1017/CB09781107415324.004

Slavin, Robert E. (1983). Cooperative Learning. Maryland: John Hopkins University.

Soetjipto dan Rafflis. (1999). Profesi Keguruan. Jakarta : Renika Cipta.

Suyatno. (2008). Dinamika Pendidikan Nasional. Jakart: PSAP.

Syaefudin U.S.(2009). Pengembangan Profesi Guru . CV. Alfabeta.

Undang-Undang Republik Indonesia No. 14 tahun 2005 Tentang Guru dan Dosen serta UU No.20 Tahun 2003 Tentang Sisdiknas .Bandung : Citra Umbara. 